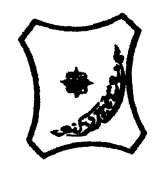

Bayero Journal of Pure and Applied Sciences, 13(2): 72 - 78

Received: July, 2020

Accepted: October, 2020

ISSN 2006 - 6996

\title{
HEAMATOLOGICAL PARAMETERS OF ONE HUMP CAMELS (Camelusdromedarius) IN NORTH WESTERN NIGERIA
}

\author{
Ibrahim, H. M., ${ }^{1}$ Bulama, I., ${ }^{2}$ Bashir, S., ${ }^{1}$ Abubakar,S. I. ${ }^{3}$ and Ali, W. ${ }^{4}$ \\ 1 Department of Veterinary Physiology and Biochemistry Faculty of Veterinary Medicine Usman \\ Danfodiyu University Sokoto Sokoto State Nigeria \\ 2 Department of Veterinary Physiology and Biochemistry Faculty of Veterinary Medicine University of \\ Maiduguri, Borno State Nigeria \\ 3 Veterinary clinic Ministry of Animal and Fishery Sokoto Sokoto state Nigeria \\ 4 Department of Veterinary Pathology Faculty of Veterinary Medicine University of Maiduguri Borno \\ State Nigeria
}

\begin{abstract}
Camels are regarded as the ship of the desert, being used for transporting humans and their goods. They are also raised for milk, meat, hides and wool. Normal haematological values are important as disease diagnostic aid as they are vital indicator of the animals' health status. Haematological parameters of one- humped camels (Camelusdromedarius) were determined in this study. 60 one- humped camels (Camelusdromedarius) were selected in sokoto and their blood samples were analyze using standard procedures for haematological parameters[Packed cell volume (PCV), red blood cells (RBC), haemoglobin (Hb), white blood cells (WBC), neutrophils, eosinophils, Basophils, monocyte, Iymphocyte, mean corpuscular volume (MCV), mean corpuscular haemoglobin (MCH), and mean corpuscular haemoglobin concentration (MCHC)].For all the parameters, only neutrophils and MCV values showed significant variation between sexeswith male camels having higher values than females. There is variation in the range values for all the parameters between sexes except Basophils, Monocyte and Lymphocyte. Base on the results of this study, the values were similar in both sex except in neutrophils and mean corpuscular volume indicating insignificant effect of sex on most of the haematological parameters.
\end{abstract}

\section{INTRODUCTION}

Camels are regarded as the ship of the desert, being used for transporting humans and their goods. They are also raised for milk, meat, hides and wool. In Nigeria, the development is a growing increase in their contribution to human protein supply (Wilson, 1984; Zakari et al., 1988). They are important player in the food security of the nomadic pastoralist (El-Naya \& Barghash, 2016) and in the economy of northern Nigeria (FDLPCS, 1992). They have high working capacity and add value to environmental preservation (Chafe et al., 2003). Phenotypic features of the camels are influenced by geographical locations (Yahaya et al. 2012). They are genetically diverse with varied colour phenotype within the gene pool (Abdussamad et al. 2015), but breed definitions are unavailable within the camel population in the country (Waziri et al., 2019). The national camel population has been estimated to be 90,000 (Bourn et al. 1994) and are mostly found in
Borno, Jigawa, Kano, Kastina, Kebbi, Sokoto, Yobe and Zamfara States where they are reared as sedentary or pastoral herds (Jajiet al. 2017).In recent times there has been a sound increase in the number of camels slaughtered for meat in Sokoto and other cities in the region due to increasing cost of cattle and the decline in number of other livestock species. Daily 1625 camels are being slaughtered at the Sokoto metropolitan abattoir (MANR, 2002). Camels are hardy animals that have a strong adaptation to the harsh weather conditions of arid regions because of their unique physiological characteristics (Karimi et al., 2014). Despite their role as a member of the food producing family of livestock, camels have for a long time remained the most neglected animal in the field of scientific research.

Haematology is becoming an increasingly important diagnostic and management tool in veterinary medicine, globally (Tharwat et al., 2015). 
BAJOPAS Volume 13 Number 2,December, 2020

The blood picture of an animal provides an opportunity to clinically investigate the presence of different metabolites and other constituents in the body of the animal and it plays a vital role in the assessment of physiological, nutritional and pathological status of an animal (Ghoneim et al. 2014;Doyle, 2006). It also helps in distinguishing the normal state from the state of stress, which can be nutritional, environmental or physical (Aderemi, 2004). In order to interpret the results obtained in the laboratory, comparison with normal reference values of clinically healthy animals has to be made which serve as an index to the clinician. Unsuitable reference values may lead to further investigations or wrong diagnosis (Tsang et al.,1998).

It is not recommended to use haematological values reported from different environments and conditions as reference values in our local breed of animals since geographical variations in haematological values exist (Ezeilo, 1972; Gul et al., 2007). Such variations are attributed to environmental factors especially dietary habits (Ezeilo, 1972; Enyikwola and Ghoshal 1989) and other factors such as species, breed, sex, age, nutrition, illness, stress, exercise, transport, and season (Jain, 1998). The haematological parameters reported for dromedarycamelsin northern Nigeria (Fatihu et al. 2000; Kamalu et al. 2003) seemed to partially fit into the previously reported reference values from different global locations (Al-Haj, 2013; Vap and Andrea, 2014; Farooq et al., 2011). Because the available data is inconsistent, having a wide range of values, which are in disagreement with each other. Values reported as normal reference were obtained on relatively small and undefined groups of animals with no reference to age, sex and environmental condition. This study was therefore aimed to evaluate the haematological parameters of the one-humped camels in Nigeria.

\section{MATERIALS AND METHODS \\ Study location}

The study location is Sokoto south local government, Sokoto state in north-west Nigeria. This state shares border with Zamfara and Kebbi state, and Federal Republic of Niger. It covers a total land area of $101,735 \mathrm{~km}^{2}$ with an estimated human population of $3,702,676$ (NPC, 2006).

\section{Animals for study}

The study population was 60 apparently healthy camels presented for slaughter (32 males and 28 females) to the abattoir and the sex of each sampled animal were observed and recorded appropriately.

\section{Blood sample collection}

Blood samples for the haematological analysis were collected from the jugular vein into labelled sample bottle containing ethylene diaminetetracetic acid (EDTA). The samples were then transported on ice to the veterinary physiology laboratory in the department of Veterinary Physiology and Biochemistry UsmanDanfodiyo University Sokoto for haematological analysis.

\section{Haematological analysis}

The blood samples were analyzed using the following methods; the packed cell volume (PCV) was measured using the microhaematocrit method (Brar et al., 2000). The red blood cells (RBC) count and white blood cells (WBC) count were done with a haemocytometer (Braret al ., 2000), the differential leukocyte counts was performed on thin smear stained with Leishman stain (Coles, 1986). The haemoglobin (Hb) concentration was determined by the cyanomethaemoglobin method. The mean corpuscular volume (MCV), the mean corpuscular haemoglobin $(\mathrm{MCH})$ and the mean corpuscular haemoglobin concentration (MCHC) are determined using standard formula (Coles, 1986).

\section{RESULTS}

For all the 60 camels ( 32 males and 28 females) examined, the mean PCV value for females is found to be higher than that of the males although not statistically significant $(p>0.05)$ (Table 1).The mean RBC count for females was found to be higher than that of males also with no significant difference $(p>0.05)$ (Table 1$)$. Both sexes have same upper and lower limit (Table 1).Male camels was found to have higher mean WBC count than their female counterpart though not statistically significant $(p>0.05)$ (Table 2).

From Table 1, mean haemoglobin concentration for females is higher than that of the males also with no statistically significant $(p>0.05)$ difference (Table 1)but males have wider range than females

The values for differential leucocytes count indicated that the mean eosinophils and neutrophils were higher in males while the mean basophils values is higher in females but only variation in neutrophils is significantly $(p<0.05)$ different (Table 2).

The mean MCV value for males is significantly $(p<0.05)$ higher than that of females while the mean $\mathrm{MCH}$ and $\mathrm{MCHC}$ were insignificantly higherin female camels (Table 1 ). 
Table 1:Mean \pm SD and Range of the Haematological Erythrocytic valuesof Camelusdromedarius

\begin{tabular}{|c|c|c|c|c|}
\hline Parameter & & Range & Mean \pm SD & $\begin{array}{c}\text { Level of } \\
\text { significance } \\
\text { (P- value) }\end{array}$ \\
\hline \multirow{3}{*}{$\overline{\text { PCV (\%) }}$} & All & $19-45$ & $27.95 \pm 7.11$ & \multirow{3}{*}{$p>(0.05)$} \\
\hline & Males & $19-45$ & $27.41 \pm 7.24$ & \\
\hline & Females & $20-44$ & $28.57 \pm 6.91$ & \\
\hline RBC $\left(\times 10^{6}\right.$ & All & $4.00-13.05$ & $6.62 \pm 2.42$ & \multirow{3}{*}{$p>(0.05)$} \\
\hline \multirow[t]{2}{*}{ cells $/ \mathrm{mm}^{3}$ ) } & Males & $4.00-13.00$ & $6.21 \pm 2.45$ & \\
\hline & Females & $4.11-13.05$ & $7.09 \pm 2.45$ & \\
\hline Haemoglobin & All & $7.27-16.35$ & $11.00 \pm 2.57$ & \multirow{3}{*}{$\mathrm{p}>(0.05)$} \\
\hline concentration & Males & $6.89-16.22$ & $10.62 \pm 2.53$ & \\
\hline \multirow{2}{*}{$(g / d L)$} & Females & $7.27-16.35$ & $11.44 \pm 2.37$ & \\
\hline & All & $29.61-65.78$ & $43.95 \pm 7.35$ & \multirow{4}{*}{$\mathrm{P}<(0.05)^{*}$} \\
\hline \multirow[t]{3}{*}{$\operatorname{MCV}(f L)$} & Males & $33.47-65.78$ & $46.13 \pm 7.72$ & \\
\hline & Females & $29.61-47.35$ & $41.47 \pm 6.00$ & \\
\hline & All & $8.58-37.81$ & $18.28 \pm 6.98$ & \\
\hline \multirow[t]{3}{*}{$\mathrm{MCH}(\mathrm{pg})$} & Males & $8.58-37.81$ & $18.88 \pm 7.35$ & \multirow[t]{3}{*}{$\mathrm{p}>(0.05)$} \\
\hline & Females & $9.08-37.47$ & $17.60 \pm 6.47$ & \\
\hline & All & $24.32-81.50$ & $41.75 \pm 15.11$ & \\
\hline MCHC $(g / d L)$ & Males & $24.32-81.18$ & $41.07 \pm 15.41$ & \multirow[t]{2}{*}{$p>(0.05)$} \\
\hline & Females & $25.13-81.50$ & $42.56 \pm 14.73$ & \\
\hline
\end{tabular}

Key: P-values with asterisk shows that there is significant statistical variation in the mean obtained between males and females, $\mathrm{PCV}=$ packed cell volume, $\mathrm{RBC}=$ red blood cells count, $\mathrm{MCV}=$ mean corpuscular volume, $\mathrm{MCH}=$ mean corpuscular haemoglobin, $\mathrm{MCHC}=$ mean corpuscular haemoglobin concentration

Table 2:Mean \pm SD and Range of the Haematological Leucocytic values of Came/usdromedarius

\begin{tabular}{|c|c|c|c|c|}
\hline Parameter & Sex & Range & Mean \pm SD & $\begin{array}{c}\text { Level of } \\
\text { significance } \\
\text { (P- value) }\end{array}$ \\
\hline WBC $\left(\times 10^{6}\right.$ & All & $6.20-22.75$ & $13.45 \pm 4.20$ & $p>(0.05)$ \\
\hline \multirow[t]{2}{*}{ cells $/ \mathbf{m m}^{3}$ ) } & Males & $7.09-22.75$ & $13.96 \pm 3.94$ & \\
\hline & Females & $6.20-21.35$ & $12.94 \pm 4.57$ & \\
\hline Lymphocytes & All & $30-59$ & $48.05 \pm 5.99$ & \\
\hline \multirow[t]{2}{*}{$(\%)$} & Males & $30-58$ & $48.37 \pm 6.02$ & $p>(0.05)$ \\
\hline & Females & $32-59$ & $47.68 \pm 6.15$ & \\
\hline \multirow[t]{3}{*}{ Neutrophils (\%) } & All & $18-43$ & $31.28 \pm 6.99$ & \\
\hline & Males & $20-41$ & $33.03 \pm 5.92$ & $\mathrm{P}<(0.05)^{*}$ \\
\hline & Females & $18-43$ & $29.28 \pm 7.78$ & \\
\hline \multirow{3}{*}{ Eosinophils (\%) } & All & $2-10$ & $6.43 \pm 2.32$ & \\
\hline & Males & $3-10$ & $6.81 \pm 2.42$ & $p>(0.05)$ \\
\hline & Females & $2-9$ & $6.00 \pm 2.19$ & \\
\hline \multirow[t]{3}{*}{ Basophils (\%) } & All & $0-1$ & $0.33 \pm 0.47$ & \\
\hline & Males & $0-1$ & $0.31 \pm 0.47$ & $p>(0.05)$ \\
\hline & Females & $0-1$ & $0.36 \pm 0.48$ & \\
\hline \multirow{3}{*}{ Monocytes (\%) } & All & $7-10$ & $8.47 \pm 1.26$ & \\
\hline & Males & $7-10$ & $8.47 \pm 1.43$ & $p>(0.05)$ \\
\hline & Females & $7-10$ & $8.46 \pm 1.07$ & \\
\hline
\end{tabular}

Key: P-values with asterisk shows that there is significant statistical variation in the mean obtained between males and females, WBC = white blood cells count

\section{DISCUSSION}

The purpose of this study was to determine the normal haematological parameters of one humped camel (Camelusdromedarius) with sex difference in Sokoto northwest Nigeria. The results for all the animals showed wide range of
PCV (19-45\%) with mean value of $27.97 \%$.This is similar with the report of Fatihu et al.,(2000) who reported the normal meanpcv to be $27.94 \%$ but Bogin, (2000) reported a higher mean PCV value of $30 \%$ while Kamalu et al., (2003) reported slightly higher value of $28.79 \%$. 
BAJOPAS Volume 13 Number 2,December, 2020

The range obtained in this study is higher than that reported by Kamalu et al., (2003)(2040.5\%) and Bogin, (2000) (24-35\%). Vapand Andre(2014) reported normal range of PCV as 27-45 which has upper limit in agreement with this study. However sex was observed to have no statistically significant ( $P>0.05)$ effect on PCV though the mean value $(7.24 \%)$ in female camels is higher than that obtained in males (6.91\%). Farooqet al., (2011) also reported higher PCV values in female. But Anwar et al., (2019) reported significantly higher PCV value in female camels. These differences could have physiological basis as variations in such parameters may be associated with the varied levels of responses to the effects of catecholamine and glucocorticoid released during environmental stress, trekking and handling (Tornquist, 2010). Adah et al., (2017) reported that trekking and loaded camels, with associated stress, had some increases in PCV and TLC.

The mean value of RBC obtained in this study was $6.62 \times 10^{6} \mathrm{cell} / \mathrm{mm}^{3}$ with range of 4.00 $13.05 \times 10^{6} \mathrm{cell} / \mathrm{mm}^{3}$. The mean value obtained is lower than the mean $\left(8.9 \times 10^{6}\right.$ cell $\left./ \mathrm{mm}^{3}\right)$ obtained by $\mathrm{Al}-\mathrm{Haj}, \quad(2013)$ and $\left(7.6 \times 10^{6} \mathrm{cell} / \mathrm{mm}^{3}\right)$ by Bogin (2000). The range obtained in this report is in agreement with that reported by Kamalu et al., (2003) while Bogin, (2000) reported narrow range of $6-9.2 \times 10^{6} \mathrm{cell} / \mathrm{mm}^{3}$. Comparison between sex shows no statistically significant ( $P>0.05)$ difference but RBC value $\left(7.09 \times 10^{6} \mathrm{cell} / \mathrm{mm}^{3}\right)$ in female camels is slightly higher than that obtained in males $\left(6.21 \times 10^{6} \mathrm{cell} / \mathrm{mm}^{3}\right)$. This is in agreement with the work reported by Farooq et al.,(2011) on one humped camels in which females were reported to have slightly higher RBC values than the males.

The mean total leucocyte count (WBC) in this work was found to be $13.45 \times 10^{3} \mathrm{cell} / \mathrm{mm}^{3}$ with the range of $6.20-22.75 \times 10^{3} \mathrm{cell} / \mathrm{mm}^{3}$. This is in agreement with the report of Bogin, (2000) but Fatihu et al. (2000) reported slightly higher $\left(15.18 \times 10^{3} \mathrm{cell} / \mathrm{mm}^{3}\right)$ values than the result of this study. While Kamalu et al., (2003) and $\mathrm{Al}-\mathrm{Haj},(2013)$ reported $25.6 \times 10^{3} \mathrm{cell} / \mathrm{mm}^{3}$ and $10.7 \times 10^{3}$ cell $/ \mathrm{mm}^{3}$ respectively which are not in agreement with what is obtained in this study. However, there is no statistically significant difference between WBC of males and that of the females camels $(P>0.05)$. This supports the work of Farooq et al. (2011), Which observed that the mean total leucocytes count to be similar in males and females. The predominant white cell is the lymphocyte followed by neutrophils, few monocyte and eosinophils and rare basophils. This supports the leucocyte count reported by Khalid, (2007) in different breeds of camel in Saudi Arabia. However, Jirimutu and Guohui, (2012) reported neutrophils as the predominant leucocyte in Bactrian (two-hump camel). The difference could be associated with breed difference or stress condition. Usually, during stress or excitement, epinephrinemediated physiological leukocytosis causes both neutrophilia and lymphocytosis when there is a balance in leukocyte responses; but leukocytosis, inastressleukogram induced by glucocorticoids, is duetomatureneutrophilia and Iymphopenia, and it makes the neutrophil count to increase while the lymphocyte count decreases (Waziri et al., 2019).

The mean relative neutrophils of $31.28 \%$ with range of $18-43 \%$ in this study is much lower than the $50 \%$ obtained byBogin, (2000) but higher than the $25.16 \%$ reported by kamalu et al., (2003). While the range by Bogin. (2000) of $20-40.9 \%$ is slightly lower than the result of this study. According to this study, there is statistically significant ( $p<0.05$ ) difference between number of neutrophils in males and females with mean value of $29.28 \%$ in females and $33.03 \%$ in males. Similar results was reported by Anwar et al., (2019) but Farooq et al. (2011) reported no significant variation with sex.

The mean relative lymphocytes value in this study $(48.05 \%$ ) (Range $=30-59 \%$ ) is higher thanthe value (41\%) reported by Bogin, (2000) \& $(45.00 \%)$ by Kamalu et al. (2003). And according to this study, there is no statistically significant difference between the mean lymphocytes in males and females.

The mean eosinophil in this study $6.43 \%$ is similar to that of Kamalu et al., (2003) who reported the mean value of 6.85 . While the result by Bogin, (2000) is $3 \%$ which falls within the range obtained in this study. No significant difference was observed between males and females values.

The mean monocyte $(8.47 \%)$ in this study was found to be higher than that $(4 \%)$ reported by Bogin., (2000) and lower than that (12.56\%) of kamalu et al., (2003). While the range (7$28 \%$ )obtained by Kamalu et al., (2003) has high upper limit than the range (7-10\%) in this study. The mean basophil in this study was found to be $0.33 \%$ with range of $0-1 \%$. Vap and Andre (2014), also reported mean value of $<1 \%$ while Kamalu et al., (2003) reported a high mean value of $5.06 \%$ and Bogin, (2000) obtained similar range $(1 \%)$ value. The range $(0-1 \%)$ for males and females is same as reported by Farooq et al. (2011). 
BAJOPAS Volume 13 Number 2,December, 2020

The mean haemoglobin concentration obtained in this study is $11.00 \mathrm{~g} / \mathrm{dl}$ with a range of 7.2716.35.Bogin, (2000) and Fatihu et al.(2000) also reported same value of mean haemoglobin concentration, while Al-Haj, (2013) and kamalu et al., (2003) reported the mean as $12.1 \mathrm{~g} / \mathrm{dl}$ and $12.04 \mathrm{~g} / \mathrm{dl}$ respectively which are slightly above the mean in this study. The result also showed that haemoglobin concentration in females is slightly higher than that in males which is contrary to the report of Farooq et al. (2011) which showed that the haemoglobin concentration in males is slightly higher than that of females. Significant effect of sex on $\mathrm{Hb}$ concentration was observed by Anwar et al., (2019) with females having higher values than male camels

The mean for mean corpuscular haemoglobin $\mathrm{MCH}$ and mean corpuscular haemoglobin

\section{REFERENCES}

Abdussamad AM, Charruau P, Kalla DJU, Burger PA (2015) Validating local knowledge on camels: colour phenotype and genetic variations of dromedaries in NigeriaNiger corridor. LivestSci 181:131-136

Aderemi, F. A. (2004). Effect of replacement of wheat bran with cassava root sieviate supplemented or unsupplemented with enzyme on the hematology and serum biochemistry of pullet chicks. Tropical Journal of Animal Science.7: 147-153.

Adah AS, Ayo JO, Rekwot PI, Arimie DI (2017) Haematological profileof the onehumped camel subjected to packing (load carrying) in harmattan season in semi-arid region of Nigeria. Bangl J Vet Med15(1):39-44

Aengwanich, W., A. Chantiratikul\& S. Pamok (2009). Effect of seasonal variations on hematological values and health monitor of cross bred beef cattle at slaughterhouse in north-eastern part of Thailand. American-Eurasian Journal of Agriculture and Environmental Science, 5 (5): 644-648.

Al-Haj M, Kazzam E, Nagelkerke NJ, Nyberg F, Nicholls MG and Adem A. (2011).Effect of Dehydration in the Presence and Absence of the Angiotensin Receptor Blocker Losartan on Blood Constituents in the Camel. Journal of Medical Sciences, 4(2): 73-78

Anwar, M.A., Fathia, M.B., Mansur, E.S., Fahima, A. A., Ismail, M.A., and Amal, O. B. (2019). Blood Profile in Normal One Humped Dromedary (Camelus dromedarius) Camels in Libya. Part 3: Effect of Sex Variation on Biochemical concentration MCHC did not vary significantly between males and females but significant variation with sex was observed in mean corpuscular volume MCV with males having higher value than females.

\section{CONCLUSION}

Base on the results of this study, sex was found to have significant effect on neutrophils and mean corpuscular volume which could be as a result of hormonal influence. Also some of the haematological parameters obtained in this study were found to vary from values obtained from other studies conducted in camels which could be due to difference in geographical location, weather, season, type of feed, husbandry or assay method

and Haematological Blood Profile. International Journal of Sciences: Basic and Applied Research 48 (1); 9-24

Bogin, E. (2000).Clinical Pathology Of Camelides: present and future. Revue Med. Vet., 151, 7, 563-568.

Blench, R. (1999). Traditional Livestock Breeds: Geographical distribution and dynamics in relation to the ecology of West Africa: Overseas Development Institute Portland House Stag Place London; 122. PP: 7-21.

Brar, R.S., Sandhu, H.S. and Singh, A. (2000). Veterinary Clinical Diagnosis by Laboratory Methods . 1st Ed. India: Kaylani Publishers, pp:29-150

Bourn, D., Wint, W., Blench, R. and Wooley, E. (1994). Nigerian livestock research survey. World Animal Review 78: 49-58

Chafe, U.M., Musa, A. \&Dogara, B. (2003). Studies of some health aspects of traditional camel management in Northwestern Nigeria.Livestock Research for Rural Development , 20(2): 14pp.

Coles, EH., (1986). Veterinary clinical pathology $4^{\text {th }}$ Ed. Philadelphia: WB Saunders Co. Pp 53-55

Doyle, D. (2006). William Hewson (1739-1774): The father of hematology. Br. J. Haematol. 133: 375- 381.

El-Naga, T.R.A. \& Barghash, S.M. (2016). Blood Parasites in Camels (Camelusdromedarius) in Northern west coast of Egypt. Bacteriology and Parasitology, 7(1):7pp.

Elitok B, Cirak AC. (2018). Clinical, Hematological and Blood Biochemical Features of Camels. MOJ Immunol, 6(5):288-295. 
BAJOPAS Volume 13 Number 2,December, 2020

Enyikwola, O. \&Ghosal, BK.(1988). Packed Cell Volume and Hemoglobin Concentration in the apparently healthy preclinical Students in the university of Maiduguri. Nigeria. Annals of Borno 5:206-210.

Ezielo G.C., (1972). Non-genetic Nutropenia in Africans.Lancet 1:1003-1005.

Farooq, U., Samad, H. A., Khurshid, A. \& Sajjad, S. (2011). Normal Reference Hematological Values Of One-Humped Camels (Camelus Dromedarius) Kept In Cholistan Desert. The Journal of Animal and Plant Sciences, 21(2): 157-160.

Fatihu M.Y., James A.S., \&Abubakar M.B. (2000). Hematological data of Healthy and Natural Trypanosomaevansi Infected Camels (Camelusdromerarius) sokoto, Nigeria. Journal of Protozoological Research. 10, 1-5

Federal Department of Livestock and Pest Control Services, FDLPCS (1992). Nigerian Livestock Resources, Vol. 2, National synthesis. Report by Resource Inventory and Management Limited, to FDLPCS, Abuja, Nigeria. 440pp.

Ghoneim IM, Waheed MM, Fouda TA, AlEknahMM,Al-Mugalli AM, El-Deeb WM, El Jalii IM (2014). Some biochemical and haematological aspects associated with pyometra and endometritis in female camels (Camelusdromedarius). J Camel Prac Res 21(1): 99-102

Gul, S. T., M. Ahmad, A. Khan, \& I. Hussain (2007). Haemato-biochemical observations in apparently healthy equine species. Pakistan Veterinary Journal.27 (4): 155-158.

Jain, N. C. (1998). Essentials of veterinary hematology.2nd Ed. Lea \&Febiger; Philadelphia (USA).pp 65-68.

Jaji, A. Z., Elelu, N., Mahre, M. B., Jaji, K., Ghali Mohammed, L. I., AuduLikita, M., Kigir1, E. S., Onwuama, K. T. and Saidu, A. S. (2017). Herd growth parameters and constraints of camel rearing in Northeastern Nigeria, Pastoralism (7); 16

Jirimutu, ZW, Guohui D. (2012). Genome sequences of wild and domestic Bactrian camels. J. Nature communication. 2012;3.

Kamalu J.N, Okpe, G. C.\& WILI.IAMS, A. (2003). Hematological studies in apparently normal adult camels
(Comelusdromedurius) of north eastsahel region of Nigeria. Global Journal of Agricultural Sciences.2 (1): 58

Karimi, A., Rahbari, S. \& Yousefi, A. (2014) Blood parasites of camels from central regions of Iran: comparative evaluation of various detection techniques and serum protein components. Journal of Advances in Parasitology, 2: 1-4.

Khalid, AA. (2007) Some Biochemical and Haematological indices in Different Breeds of Camels in Saudi Arabia.Scientific J. Of King Faisal Uni. 8(1)131-139

Vap, L. \& Andrea A. (2014). Bohn. Hematology of Camelids Veterinary clinics of North America Exotic Animal Practice.Cvex. 2014.09.010.

MANR (2002). Ministry of Agriculture and Natural Resources slaughter records 2002. Ministry of Agriculture and Natural Resources, Maiduguri, Borno State.

Schwartz, H.J. \&Dioli, M. (1992). The OneHumped Camel in Eastern Africa: A Pictorial Guide to diseases, Health care and management. Weikersheim: Verlag Josef Margraf, pp. 1-59.

Tornquist S] (2010) Hematology of camelids. In: Weiss DJ, Wardrop KJ (eds) Schalm's veterinary hematology, 6th edn. Blackwell Publishing, Ames, pp 910-917

Tsang, C. W., R. Lazarus, W. Smith, P. Mitchell, J. Koutts\& L. Burnett (1998). Hematological indices in an older population sample: derivation of healthy reference values. Clin. Chem. 44: 96101.

Tschuor, A. C., B. Riond, U. Braun \& H. Lutz (2008). Hematological and clinical biochemical reference values for adult goats and sheep. Schweiz. Arch.Tierh.150 (287-295).

Tharwat M, Ali A, Al-Sobayil F, Selim L, Abbas H (2015) Haematobiochemical profile in female camels (Camelusdromedarius) during the periparturient period. J Camel Prac Res 22(1):101-106. https://doi.org/10.5958/22778934.2015.00016.8

Wilson T.R. (1984) The camel. The print house, Pty Ltd. Singapore. 
BAJOPAS Volume 13 Number 2,December, 2020

Waziri, A., Hassan, S.U., \& Igbokwe, I.O. (2019). Haematological reference values of dromedary camels in northern Nigeria.Comparative Clinical Pathology, 2019 (28)1769-1777

Yahaya A, Olopade JO, Kwari HD, Wiam IM (2012) Investigation of osteometry of the skull of the one-humped camels part variations in adults. Ital ] AnatEmbryol 117(1):34-44

Zakari H. Sivchelvan M.N. \&Chibuzo G.A (1988). The comparative study of animal slaughter records in Maiduguri abattoir (Borno state) prior to and after 1983 rinderpest outbreak. Aanals of Borno 5:224-23 